\title{
TYPE III PNEUMONIA: THE PROGNOSTIC SIGNIFICANCE OF RETICULATION IN RELATION TO THE NUMBER OF PNEUMOCOCCI IN THE SPUTUM, THERAPY, BACTEREMIA, LEUKOCYTE COUNT, AGE, AND DEGREE OF INVOLVEMENT ${ }^{1}$
}

\author{
By ARTHUR W. FRISCH, ALVIN E. PRICE, AND GORDON B. MYERS \\ (From the Departments of Bacteriology and Internal Medicine, Wayne University College of \\ Medicine, and Receiving Hospital, Detroit) \\ (Received for publication September 15, 1942)
}

The microscopic examination of sputum from patients with pneumonia has revealed that type III infections are distinctly different from those due to other pneumococci. The outcome of type III pneumonia was correlated more closely with the presence or absence of a fibrin-like reticulum in Wright-stained smears of sputum than with the number of organisms per oil immersion field (1, $2)$. The reticulation appeared to originate from the capsules of the interdispersed pneumococci and was subsequently identified as capsular polysaccharide. A quantitative relationship was demonstrated between the degree of reticulation and the amount of SSS in the sputum and lungs (3, 4). The reticulated type III sputums contained an average of 1,360 $\mathrm{mgm}$. per cent of SSS; whereas, the non-reticulated specimens yielded an average of only $45 \mathrm{mgm}$. per cent. The amount of SSS in the sputums of the total group of type III cases exceeded by 170 times the amount recovered from types I, II, VII, and VIII cases. Autopsy studies revealed that there was 60 times more capsular polysaccharide in the lungs of type

1 Supported by a grant from the Commonwealth Fund to the Michigan Department of Health Laboratories.
III cases than in those due to the above mentioned types. The following report is based upon 114 roentgenographically proved cases of type III pneumonia which were studied by the method described in the companion publication on page 207 of this journal. The results are analyzed according to the presence or absence of reticulation in the sputum, ${ }^{2}$ as well as the number of pneumococci per oil immersion field. These findings are compared as to prognostic significance with the time-honored criteria, such as bacteremia, leukocyte count, age of the patient, and extent of consolidation.

\section{RESULTS}

The total fatality rate of 33 per cent for type III pneumonia was significantly higher than the average of 13 per cent for all other types. When the cases were grouped according to the number of pneumococci in the sputum (Table I), it was found that the fatality in group A (10 or less per field) was 11 per cent for type III, as compared

2 Four patients who were non-reticulated on admission to the hospital were finally classed in the reticulated group as the disease progressed.

TABLE I

The relation of reticulation to sputum counts

\begin{tabular}{|c|c|c|c|c|c|c|c|c|c|c|c|c|c|c|c|}
\hline \multirow{3}{*}{$\underset{\text { group }}{\text { Sputum }}$} & \multicolumn{4}{|c|}{ Non-reticulated } & \multicolumn{4}{|c|}{ Reticulated } & \multicolumn{4}{|c|}{ Total } & \multicolumn{3}{|c|}{ Other types } \\
\hline & \multicolumn{2}{|c|}{ Cases } & \multicolumn{2}{|c|}{ Deaths } & \multicolumn{2}{|c|}{ Cases } & \multicolumn{2}{|c|}{ Deaths } & \multicolumn{2}{|c|}{ Cases } & \multicolumn{2}{|c|}{ Deaths } & \multicolumn{2}{|c|}{ Cases } & \multirow{2}{*}{$\begin{array}{l}\text { Deaths } \\
\begin{array}{l}\text { Per cent } \\
\text { fatality }\end{array}\end{array}$} \\
\hline & Num- & $\begin{array}{l}\text { Per cent } \\
\text { of total }\end{array}$ & $\underset{\text { ber }}{\text { Num- }}$ & $\begin{array}{l}\text { Per cent } \\
\text { fatality }\end{array}$ & $\underset{\text { ber }}{\text { Num- }}$ & $\begin{array}{l}\text { Per cent } \\
\text { of total }\end{array}$ & $\underset{\text { ber }}{\text { Num- }}$ & $\begin{array}{l}\text { Per cent } \\
\text { fatality }\end{array}$ & Num- & $\begin{array}{l}\text { Per cent } \\
\text { of total }\end{array}$ & $\underset{\text { ber }}{\text { Num- }}$ & $\begin{array}{l}\text { Per cent } \\
\text { fatality }\end{array}$ & $\underset{\text { ber }}{\text { Num- }}$ & $\begin{array}{l}\text { Per cent } \\
\text { of total }\end{array}$ & \\
\hline $\begin{array}{l}\mathbf{A} \\
\mathbf{B} \\
\mathbf{C} \\
\mathbf{D}\end{array}$ & $\begin{array}{r}48 \\
21 \\
3 \\
0\end{array}$ & $\begin{array}{r}67 \\
29 \\
4 \\
0\end{array}$ & $\begin{array}{l}2 \\
2 \\
1 \\
0\end{array}$ & $\begin{array}{r}4 \\
10 \\
33\end{array}$ & $\begin{array}{r}5 \\
18 \\
14 \\
5\end{array}$ & $\begin{array}{l}12 \\
43 \\
33 \\
12\end{array}$ & $\begin{array}{r}4 \\
15 \\
10 \\
4\end{array}$ & $\begin{array}{l}80 \\
83 \\
72 \\
80\end{array}$ & $\begin{array}{r}53 \\
39 \\
17 \\
5\end{array}$ & $\begin{array}{r}46 \\
34 \\
15 \\
5\end{array}$ & $\begin{array}{r}6 \\
17 \\
11 \\
4\end{array}$ & $\begin{array}{l}11 \\
44 \\
65 \\
80\end{array}$ & $\begin{array}{r}320 \\
210 \\
101 \\
47\end{array}$ & $\begin{array}{r}47 \\
31 \\
15 \\
7\end{array}$ & $\begin{array}{r}2 \\
9 \\
30 \\
77\end{array}$ \\
\hline Totals & 72 & 63 & 5 & 7 & 42 & 37 & 33 & 79 & 114 & 100 & 38 & 33 & 678 & 100 & 13 \\
\hline
\end{tabular}


TABLE II

The relation of therapy to reticulation

\begin{tabular}{|c|c|c|c|c|c|c|}
\hline \multirow{3}{*}{ Therapy } & \multicolumn{3}{|c|}{ Non-reticulated } & \multicolumn{3}{|c|}{ Reticulated } \\
\hline & \multirow{2}{*}{ Cases } & \multicolumn{2}{|c|}{ Deaths } & \multirow{2}{*}{${ }_{\substack{\text { Num- } \\
\text { ber }}}^{\text {Cases }}$} & \multicolumn{2}{|c|}{ Deaths } \\
\hline & & Num- & $\begin{array}{l}\text { Per cent } \\
\text { fatality }\end{array}$ & & $\underset{\text { ber }}{\text { Num- }}$ & $\begin{array}{l}\text { Per cent } \\
\text { fatality }\end{array}$ \\
\hline $\begin{array}{l}\text { Supportive......... } \\
\text { Serum } \ldots \ldots \ldots \\
\text { Sulfanilamide....... } \\
\text { Drug and serum*.... }\end{array}$ & $\begin{array}{l}9 \\
6 \\
4 \\
2\end{array}$ & $\begin{array}{l}1 \\
0 \\
0 \\
0\end{array}$ & & $\begin{array}{l}6 \\
6 \\
2 \\
1\end{array}$ & $\begin{array}{l}6 \\
6 \\
2 \\
1\end{array}$ & \\
\hline Totals......... & 21 & 1 & 5 & 15 & 15 & 100 \\
\hline $\begin{array}{l}\text { Sulfapyridine....... } \\
\text { Sulfathiazole....... } \\
\text { Sulfadiazine....... } \\
\text { Drug and serum*... }\end{array}$ & $\begin{array}{r}18 \\
33 \\
0 \\
0\end{array}$ & $\begin{array}{l}2 \\
2 \\
0 \\
0\end{array}$ & & $\begin{array}{r}5 \\
13 \\
1 \\
8\end{array}$ & $\begin{array}{l}4 \\
6 \\
1 \\
7\end{array}$ & \\
\hline Totals & 51 & 4 & 8 & 27. & 18 & 67 \\
\hline
\end{tabular}

* The term drug and serum refers to serum plus sulfanilamide in contrast to serum plus sulfapyridine, sulfathiazole, or sulfadiazine.

with the rate of 2 per cent for all other types. The corresponding figures for group B (11 to 30 per field) were 44 per cent and 9 per cent; those for group C ( 31 to 75 ) were 65 per cent and 30 per cent, respectively. A further classification of these cases into those with and without reticulation served to clarify this discrepancy. As shown in Table $I$, the fatality rates in the non-reticulated cases of 4 per cent for group A, 10 per cent for group B, and 33 per cent for group C, were comparable with the averages for all other types. The reticulated cases, however, showed a uniformly high fatality, approximating 80 per cent, irrespective of the number of pneumococci in the sputum. The independent effect of reticulation on the outcome supports the concept that the ability of the type III pneumococcus to produce capsular polysaccharide is highly significant in prognosis. That the number of pneumococci in the sputum also plays a role is shown by two observations: (a) the fatality rate in the non-reticulated cases was proportional to the number of pneumococci in the sputum, and $(b)$ the incidence of reticulation in the total group of type III cases was 25 per cent when the sputum count was less than 30 , as compared with 86 per cent when it exceeded 30 per field. Because reticulation was a more accurate index of the severity of type III pneumonia, it has replaced sputum counts in the remaining tables as a basis for comparison with other prognostic factors.

The analysis of the outcome in reference to therapy is presented in Table II. The fatality rate in the non-reticulated cases was as low with serum, sulfanilamide, and even with supportive treatment, as it was with modern chemotherapeutic agents. The superiority of sulfapyridine and sulfathiazole became evident in the reticulated cases where the fatality was lowered from 100 to 67 per cent. This significant reduction in fatality does not entirely account for the well known beneficial results with sulfapyridine and sulfathiazole in type III pneumonia. The effectiveness of these drugs is also due to their ability to decrease the number of pneumococci in the sputum of nonreticulated cases, thereby preventing the formation of excessive amounts of capsular polysaccharide as the disease progresses. To date, not a single nonreticulated case of type III pneumonia has become reticulated while under treatment with sulfapyridine or sulfathiazole, whereas four such patients developed reticulation during the administration of large doses of serum and subsequently expired.

TABLE III

The relation of bacteremia to reticulation

\begin{tabular}{|c|c|c|c|c|c|c|c|c|c|c|c|}
\hline \multirow{3}{*}{ Sputum group } & \multicolumn{4}{|c|}{ Negative blood culture } & \multicolumn{4}{|c|}{ Positive blood culture } & \multicolumn{3}{|c|}{ Totals } \\
\hline & \multicolumn{2}{|c|}{ Cases } & \multicolumn{2}{|c|}{ Deaths } & \multicolumn{2}{|c|}{ Cases } & \multicolumn{2}{|c|}{ Deaths } & \multicolumn{2}{|c|}{ Cases } & \multirow{2}{*}{$\begin{array}{l}\text { Deaths } \\
\begin{array}{l}\text { Per cent } \\
\text { fatality }\end{array}\end{array}$} \\
\hline & $\underset{\text { ber }}{\text { Num- }}$ & $\begin{array}{l}\text { Per cent } \\
\text { of total }\end{array}$ & Num- & $\begin{array}{l}\text { Per cent } \\
\text { fatality }\end{array}$ & $\underset{\text { ber }}{\text { Num- }}$ & $\begin{array}{l}\text { Per cent } \\
\text { of total }\end{array}$ & Num- & $\begin{array}{l}\text { Per cent } \\
\text { fatality }\end{array}$ & $\underset{\text { ber }}{\text { Num- }}$ & $\begin{array}{l}\text { Per cent } \\
\text { of total }\end{array}$ & \\
\hline $\begin{array}{l}\text { Non-reticulated...... } \\
\text { Reticulated......... }\end{array}$ & $\begin{array}{l}67 \\
17\end{array}$ & $\begin{array}{l}80 \\
20\end{array}$ & $\begin{array}{r}4 \\
11\end{array}$ & $\begin{array}{r}6 \\
65\end{array}$ & $\begin{array}{r}1 \\
21\end{array}$ & $\begin{array}{r}5 \\
95\end{array}$ & $\begin{array}{r}0 \\
18\end{array}$ & $\begin{array}{r}0 \\
86\end{array}$ & $\begin{array}{l}68 \\
38\end{array}$ & $\begin{array}{l}64 \\
36\end{array}$ & $\begin{array}{r}6 \\
76\end{array}$ \\
\hline Totals........... & .84 & 79 & 15 & 18 & 22 & 21 & 18 & 82 & 106 & 100 & 31 \\
\hline
\end{tabular}


The low bacteremic incidence of 21 per cent associated with a high fatality rate of 82 per cent in bacteremic type III pneumonia is representative of other reports in the literature. In Table III, the results are analyzed with reference to reticulation and to blood culture. Reticulation was present in 95 per cent of the 22 bacteremics, including all 18 who died. Among the 84 non-bacteremic cases, only 20 per cent were reticulated, but these included 11 of the 15 deaths. Thus, the reticulation which was almost invariably present in bacteremic type III cases may largely account for their unusual severity, since the fatality rate was also high in reticulated cases without blood stream invasion.

The role of leukopenia in the outcome of type III pneumonia is shown in Table IV. The fatality rate was 18 per. cent in the cases with leukocyte counts over $10,000,32$ per cent in those with white counts between 5,000 and 10,000 , and 77 per cent in those with less than 5,000 cells per cubic millimeter. A study of the table, however, shows that the fatality rate was uniformly low in the absence of reticulation and uniformly high in its presence, regardless of leukocyte count. The higher fatality rate in leukopenia than in leukocytosis is due to the fact that 92 per cent of the former, and only 26 per cent of the latter, had reticulated sputum. It is thus apparent that the outcome of type III pneumonia is correlated more closely with the presence or absence of reticulation than with the leukocyte count.

The data are analyzed according to age in Table V. In the non-reticulated group, 4 of the 5 deaths occurred in patients over 54 years of age. Cardiac failure was an accessory factor in the death of all 5 cases. While the fatality rate in the reticulated cases was not influenced by age, it should be noted that the incidence of reticulation increased from 0 to 50 per cent with advancing years.

The fatality rate in cases with consolidation confined to one lobe was 29 per cent as compared with 44 per cent in those with involvement of two or more lobes (Table VI). When these cases were broken down according to the presence or absence of reticulation, no significant differences were found which could be attributed to the degree of involvement. The higher fatality

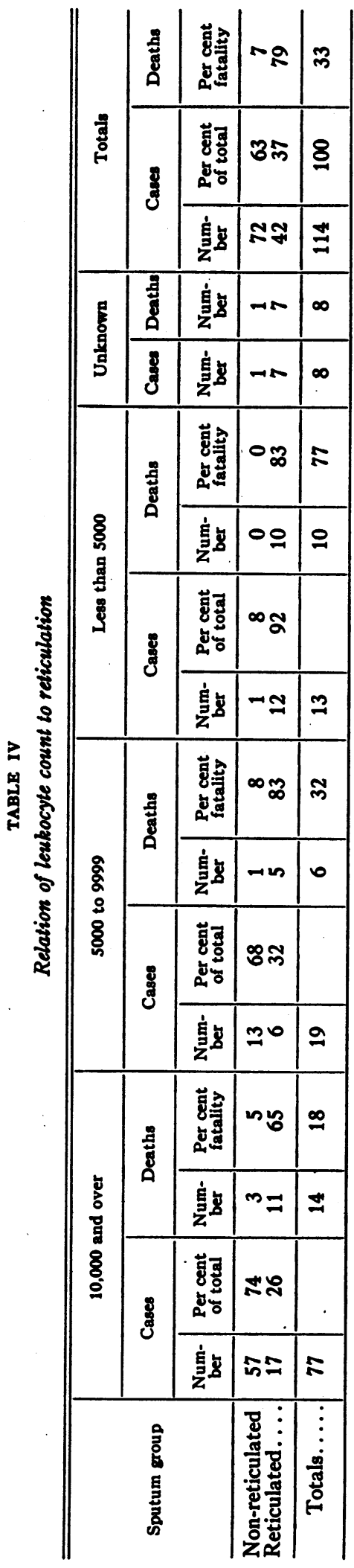




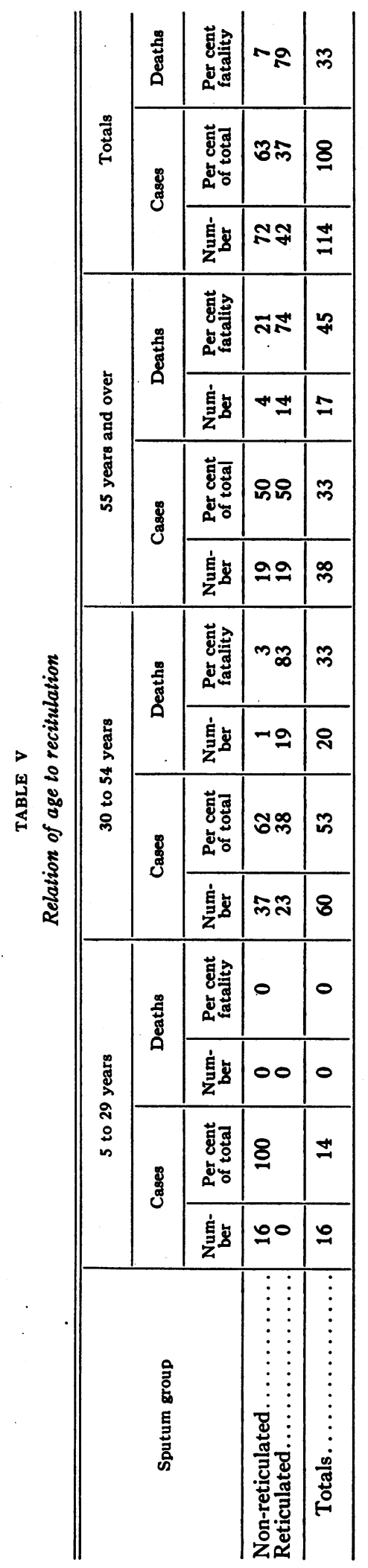

among the cases with consolidation of more than one lobe could be explained by the fact that a distinctly higher percentage showed reticulation. It would, therefore, appear that the degree of involvement in type III pneumonia does not play as significant a role in determining fatality as it does for other types.

\section{DISCUSSION}

The results in type III pneumonia differed from those obtained for all other types in two important respects. The outcome was not influenced by the degree of involvement and depended more upon the presence or absence of reticulation than upon the number of pneumococci in the sputum. The unfavorable prognosis customarily attached to the presence of bacteremia and leukopenia was attributable to the fact that reticulation was almost invariably associated with blood stream invasion or low leukocyte count. Age was the only other factor which significantly affected the outcome in type III cases. The above data, coupled with the additional evidence already presented ( 1 to 4 ), make it difficult to escape the conclusion that the prognosis in type III pneumonia is primarily influenced by the amount of SSS produced by this organism as it grows in the lungs. Such a concept may be readily correlated with other well known facts concerning the type III pneumococcus. This organism, because of the mucoid character of its growth, yields the largest amount of capsular polysaccharide under appropriate cultural conditions (5). It is also common knowledge that sputum from type III patients frequently requires dilution before exhibiting a positive Neufeld reaction. The disease induced by this pneumococcus is characterized by a predilection for the aged, a prolonged clinical course, a lobular distribution, and a relatively low bacteremic incidence, associated with a high fatality rate despite massive doses of serum (6 to 9 ). At necropsy, the consolidation has a characteristic gelatinous appearance and multiple lung abscesses are often demonstrable. In the above respects, type III more closely resembles Friedländer's pneumonia than infections due to the other common types of pneumococci $(9,10)$. The similarity between Friedländer's and type III pneumonia is further emphasized by the fact that in both diseases the 
TABLE VI

Relation of involvement to reticulation

\begin{tabular}{|c|c|c|c|c|c|c|c|c|c|c|c|}
\hline \multirow{3}{*}{ Sputum group } & \multicolumn{4}{|c|}{ One or less lobes } & \multicolumn{4}{|c|}{ More than one lobe } & \multicolumn{3}{|c|}{ Totals } \\
\hline & \multicolumn{2}{|c|}{ Cases } & \multicolumn{2}{|c|}{ Deaths } & \multicolumn{2}{|c|}{ Cases } & \multicolumn{2}{|c|}{ Deaths } & \multicolumn{2}{|c|}{ Cases } & \multirow{2}{*}{$\begin{array}{l}\text { Deaths } \\
\begin{array}{l}\text { Per cent } \\
\text { fatality }\end{array}\end{array}$} \\
\hline & $\underset{\text { ber }}{\text { Num- }}$ & $\begin{array}{l}\text { Per cent } \\
\text { of total }\end{array}$ & $\underset{\text { ber }}{\text { Num- }}$ & $\begin{array}{l}\text { Per cent } \\
\text { fatality }\end{array}$ & $\begin{array}{c}\text { Num- } \\
\text { ber }\end{array}$ & $\begin{array}{l}\text { Per cent } \\
\text { of total }\end{array}$ & $\underset{\text { ber }}{\text { Num- }}$ & $\begin{array}{l}\text { Per cent } \\
\text { fatality }\end{array}$ & $\underset{\text { ber }}{\text { Num- }}$ & $\begin{array}{l}\text { Per cent } \\
\text { of total }\end{array}$ & \\
\hline $\begin{array}{l}\text { Non-reticulated ...... } \\
\text { Reticulated......... }\end{array}$ & $\begin{array}{l}56 \\
24\end{array}$ & $\begin{array}{l}70 \\
30\end{array}$ & $\begin{array}{r}3 \\
20\end{array}$ & $\begin{array}{r}5 \\
83\end{array}$ & $\begin{array}{l}16 \\
18\end{array}$ & $\begin{array}{l}47 \\
53\end{array}$ & $\begin{array}{r}2 \\
13\end{array}$ & $\begin{array}{l}13 \\
72\end{array}$ & $\begin{array}{l}72 \\
42\end{array}$ & $\begin{array}{l}63 \\
37\end{array}$ & $\begin{array}{r}7 \\
79\end{array}$ \\
\hline Totals........... & 80 & 70 & 23 & 29 & 34 & 30 & 15 & 44 & 114 & 100 & 33 \\
\hline
\end{tabular}

high fatality rates are largely attributable to the extraordinary capacity of these organisms to form excessive amounts of capsular polysaccharide (2 to 4). The preponderance of the evidence would seem to justify the segregation of type III cases into a separate and distinct group, which requires special therapeutic, clinical, and laboratory studies.

We have not been impressed by the value of serum, either alone or coupled with sulfonamide drugs, in type III pneumonia. Several of our patients went into circulatory collapse shortly after serum was given, which suggested that harm rather than benefit had resulted from its administration. The futility of giving antibody to these patients is also obvious from the quantitative analysis for SSS, where it was shown that from 100 to 500 million units would be necessary even to neutralize the amount of polysaccharide in the lungs (3) Even in the non-reticulated cases, the sputum may become reticulated despite the administration of large doses of serum (2). For these reasons, we believe that serum should be discarded in the treatment of uncomplicated type III pneumonia except in rare instances where the pneumococci may have acquired resistance to the sulfonamide drugs.

The problem of specific treatment of type III pneumonia thus resolves itself into the use of chemotherapeutic agents of proven value. When reticulation was absent on admission to the hospital, its development was prevented by sulfapyridine and sulfathiazole. The most prompt effects in early reticulated sputum were obtained from the use of sodium sulfathiazole, in large doses, intravenously. The number of pneumococci decreased within 24 hours and the re- ticulation disappeared within 36 hours after the institution of therapy. The clinical response in reticulated cases, however, was rarely dramatic and failure to obtain improvement following a drug effect in the sputum was suggestive of complications, particularly lung abscess. The reticulated type III cases are still a therapeutic challenge and, together with group $C$ and $D$ cases due to other types of pneumococci, are suitable for the final evaluation of new agents that have proved effective in experimental infections and in the milder human pneumonias.

\section{SUMMARY}

The type III pneumococcus differs from all other pneumococci in its capacity to produce excessive amounts of capsular polysaccharide, as manifested by a fibrin-like reticulum in Wrightstained smears of rusty sputum. In the present study of 114 cases of type III pneumonia, reticulation in the sputum was by far the most important factor in determining the outcome. Thus, the fatality rate was 79 per cent when reticulation was present and only 7 per cent when it was absent. Furthermore, the fatality in reticulated cases was uniformly high, regardless of the number of pneumococci in the sputum, the blood culture, the leukocyte count, and the extent of the consolidation, but was partially influenced by the factor of age. The unfavorable prognostic significance customarily attached to bacteremia and leukopenia in type III pneumonia was attributable to the fact that reticulation was almost invariably present in such cases. The outcome in the non-reticulated cases, as in the other types, was dependent upon the number of pneumococci 
per field in the sputum. Sulfapyridine and sulfathiazole were superior to serum and sulfanilamide in the treatment of type III pneumonia because they prevented the formation of reticulation, and reduced the fatality rate in reticulated cases from 100 to 67 per cent.

The authors are deeply indebted to Dr. A. B. Mitchell for his assistance and advice in the preparation and analysis of the tables.

\section{BIBLIOGRAPHY}

1. Frisch, A. W., Sputum studies in pneumonia as an aid in prognosis. Am. J. Clin. Path., 1940, 10, 472.

2. Frisch, A. W., Sputum studies in type III pneumonia. Am. J. Clin. Path., 1940, 10, 873.

3. Frisch, A. W., Tripp, J. T., Barrett, C. D., and Pidgeon, M. S., The specific polysaccharide content of pneumonic lungs. J. Exper. Med., 1942, 76, 505.
4. Tripp, J. T., Frisch, A. W., Barrett, C. D., and Pidgeon, M. S., The specific polysaccharide content of pneumonic sputums. J. Exper. Med., 1942, 76, 497.

5. Dochez, A. R., and Avery, O. T., The elaboration of specific soluble substance by pneumococcus during growth. J. Exper. Med., 1917, 26, 477.

6. Blake, F. G., Observations on pneumococcus type III pneumonia. Ann. Int. Med., 1931, 5, 673.

7. Cecil, R. L., Baldwin, H. S., and Larsen, N. P., Clinical and bacteriologic study of 2000 typed cases of lobar pneumonia. Arch. Int. Med., 1927, 40, 253.

8. Finland, M., and Sutliff, W. D., Infections with pneumococcus types III and VIII. Arch. Int. Med., 1934, 53, 481.

9. Heffron, R., Pneumonia : With Special Reference to Pneumococcus Lobar Pneumonia. The Commonwealth Fund, New York, 1939.

10. Belk, W. P., Pulmonary infections by Friedländer's bacillus. J. Infect. Dis., 1926, 38, 115. 